\title{
IbM MEMADUKAN PENGUSAHA BATU BATA DAN PETANI PEMILIK LAHAN DALAM MENINGKATKAN KUALITAS TANAH DAN BENTUK LAHAN
}

\author{
Sudadi, Suwarto, Suryono \\ Program Studi Ilmu Tanah, Fakultas Pertanian UNS Surakarta \\ Email : sudadi62@staff.uns.ac.id
}

\begin{abstract}
ABSTRAK
Program IbM ini bekerjasama dengan dua mitra, yaitu: (1) UKM Pengusaha Batu Bata "Suko Makmur", dan (2) Kelompok Tani "Krido Tani". Mitra (1) berlokasi di Dusun Tulakan, Desa Sukoharjo, Kecamatan Tirtomoyo, Kabupaten Wonogiri. Bidang usaha yang dikembangkan oleh mitra (1) tersebut adalah usaha pembuatan batu bata. Mitra (2) juga berlokasi di Dusun Tulakan, Desa Sukoharjo, Kecamatan Tirtomoyo, Kabupaten Wonogiri. Bidang usaha yang dikembangkan oleh mitra (2) tersebut adalah usaha pertanian tanaman padi. Mitra (1) dan Mitra (2) berjarak tempuh sekitar $65 \mathrm{~km}$ dari Fakultas Pertanian UNS. Permintaan konsumen terhadap batu bata tiada henti sejalan dengan pembangunan yang ada di wilayah tersebut. Permasalahan utama Mitra 1 (UKM Pengusaha Batu Bata "Suko Makmur yaitu hampir setiap hari membutuhkan tanah yang teksturnya halus sebagai bahan pembuat batu bata. Dalam satu minggu UKM ini rata-rata membutuhkan sekitar 5 truk tanah atau 30 ton per minggu setara dengan 120 ton per bulan. Untuk mendapatkan tanah tersebut relatif sulit. Selain hal tersebut dalam pembakaran batu bata menghasilkan limbah yang sangat banyak, berupa abu (abu sekam padi atau abu kayu bakar). Setiap kali bakar membutuhkan sekitar 3 ton sekam padi dan 1 ton kayu bakar, yang akan menghasilkan limbah sekitar 0,5 ton abu. Apabila hal ini tidak digunakan akan menumpuk sebagai limbah. Solusi yang ditawarkan untuk mengatasi permasalahan utama yang dihadapi mitra (1) adalah menghubungkan/mempertemukan dengan petani yang mempunyai tanah-tanah yang lahannya berteras kecil/sempit untuk diperlebar yang merupakan permasalahan mitra (2). Solusi yang ditawarkan untuk mengatasi permasalahan utama yang dihadapi mitra (2) adalah memperlebar teras tanah dari 2 sampai 3 bidang teras menjadi 1 bidang teras dan memulihkan tingkat kesuburan/kualitas tanah bekas galian pengambilan bahan baku batu bata, salah satunya dengan memanfaatkan abu limbah pembakaran batu bata yang menjadi permasalahan mitra (1). Hasil kegiatan adalah bahan pembuatan batu bata bagi pengusaha batu bata (Mitra 1) berupa tanah lempung yang diambil dari bagian sawah yang lebih tinggi, milik Mitra 2. Sedangkan hasil kegiatan yang diperoleh oleh Mitra 2 adalah bentuk lahan yang rata sehingga lahan sawahnya lebih luas. Hal ini akan lebih memudahkan untuk penggarapan tanahnya karena dapat dikerjakan dengan traktor tangan. Sebelumnya tidak bisa diolah dengan traktor tangan karena sempitnya lahan. Kedua mitra memperoleh manfaat ekonomi yang cukup besar karena bagi Mitra 1 tanah lempung adalah bahan utama pembuatan batu bata. Tanpa bahan tersebut usaha akan berhenti karena tidak bisa berproduksi. Sebaiknya bagi Mitra 2 mendapatkan manfaat berupa efisiensi biaya dan waktu pengolahan tanah (lahan) yang sangat signifikan.
\end{abstract}

Kata kunci: pengusaha batu bata, kualitas lahan, bentuk lahan

\section{PENDAHULUAN}

Program IbM ini bekerjasama dengan dua mitra, yaitu: (1) UKM Pengusaha Batu Bata "Suko Makmur", dan (2) Kelompok Tani "Krido Tani". Mitra (1) berlokasi di Dusun Tulakan, Desa Sukoharjo, Kecamatan Tirtomoyo, Kabupaten Wonogiri. Bidang usaha yang dikembangkan oleh mitra (1) tersebut adalah usaha pembuatan batu bata. Mitra (2) juga berlokasi di Dusun Tulakan, Desa Sukoharjo, Kecamatan Tirtomoyo, Kabupaten Wonogiri. Bidang usaha yang dikembangkan oleh mitra (2) tersebut adalah usaha pertanian tanaman padi. Mitra (1) dan 
Mitra (2) berjarak tempuh sekitar $65 \mathrm{~km}$ dari Fakultas Pertanian UNS. Permintaan konsumen terhadap batu bata tiada henti sejalan dengan pembangunan yang ada di wilayah tersebut. Kondisi mitra usaha:

UKM Pengusaha Batu Bata "Suko Makmur" merupakan UKM yang bergerak dalam usaha pembuatan batu bata. Tiap hari UKM ini membutuhkan sekitar 5 truk tanah atau 30 ton per minggu setara dengan 120 ton per bulan. Manajemen yang dikembangkan berdasarkan manajemen keluarga. Dalam satu minggu UKM ini rata-rata dapat menghasilkan sekitar 12.500 batu bata, atau 50.000 batu bata per bulan.

Kelompok Tani "Krido Tani" merupakan suatu kelompok tani yang bergerak dalam usaha pertanian tanaman padi. Lahan yang dikelola seluas 40 hektar, yang terdiri dari 46 keluarga petani. Manajemen yang dikembangkan berdasarkan kegotongroyongan/ kebersamaan.

Permasalahan Mitra 1 (UKM Pengusaha Batu Bata "Suko Makmur") : mitra usaha 1 dalam kegiatan $\mathrm{IbM}$ ini menghadapi permasalahan utama yaitu pengusaha batu bata hampir setiap hari membutuhkan tanah yang teksturnya halus yang relatif subur sebagai bahan pembuat batu bata. Dalam satu minggu

UKM ini rata-rata membutuhkan sekitar 5 truk tanah atau 30 ton per minggu setara dengan 120 ton per bulan. Untuk mendapatkan tanah tersebut relatif sulit. Selain hal tersebut dalam pembakaran batu bata menghasilkan limbah yang sangat banyak, berupa abu (abu sekam padi atau abu kayu bakar). Setiap kali bakar membutuhkan sekitar 3 ton padi sekam dan 1 ton kayu bakar, yang akan menghasilkan limbah sekitar 1,5 ton abu sekam dan 0,5 ton abu kayu bakar. Apabila hal ini tidak digunakan akan menumpuk sebagai limbah. Abu ini mengandung unsur hara yang dibutuhkan oleh tanaman terutama unsur $\mathrm{P}, \mathrm{K}, \mathrm{Ca}, \mathrm{Mg}$ dan beberapa unsur mikro yang lain $(\mathrm{Cu}$, $\mathrm{Mn}, \mathrm{Zn}, \mathrm{Fe}$ ). Permasalahan Mitra 2 (Kondisi mitra Kelompok Tani "Krido Tani") : mitra usaha 2 dalam kegiatan IbM ini menghadapi permasalahan utama yaitu dari 40 hektar lahan yang dikelola banyak yang berteras kecil-kecil, lebar teras berkisar 2 sampai 3 meter. Teras yang kecil ini dalam pengolahan tanah lebih membutuhkan banyak biaya, dan hasilnya relatif lebih rendah dibanding yang berteras lebar. Dari hal tersebut perlu 2 atau 3 teras dijadikan 1 teras, sehingga memperluas bidang olah/ bidang tanam. Namun setelah dijadikan satu, kesuburan tanah menurun karena lapis olah tanah yang di atas telah diambil untuk bahan pembuatan batu bata yang relatif lebih subur. Sehingga perlu pemulihan kesuburan tanah menjadi subur kembali.

\section{METODE PELAKSANAAN}

Solusi yang ditawarkan untuk mengatasi permasalahan utama yang dihadapi mitra (1) adalah menghubungkan/mempertemukan dengan petani yang mempunyai tanah-tanah yang lahannya berteras kecil/sempit untuk diperlebar yang merupakan permasalahan mitra (2). Sedangkan solusi yang ditawarkan untuk mengatasi permasalahan utama yang dihadapi mitra (2) adalah memperlebar teras tanah dari 2 sampai 3 bidang teras menjadi 1 bidang teras dan memulihkan tingkat kesuburan/kualitas tanah bekas galian pengambilan bahan baku batu bata, salah satunya dengan memanfaatkan abu limbah pembakaran batu bata yang menjadi permasalahan mitra (1). Pembuatan batu bata Industri batu bata adalah industri yang mengolah bahan baku tanah liat dan bahan pembantu berupa air dan pasir serta serbuk gergaji melalui proses pencampuran, pembentukan bahan, pengeringan dan pembakaran. Industri batu bata mengolah sumberdaya alam, dimana lokasinya berada dekat sumber bahan baku. Batu bata atau 
bata merah dibuat dengan bahan dasar lempung atau secara umum dikatakan sebagai tanah liat yang merupakan hasil pelapukan dari batuan keras (beku) dan batuan sedimen (Suwardono, 2002).

Sekam memiliki kerapatan jenis (bulk density) $1125 \mathrm{~kg} / \mathrm{m} 3$, dengan nilai kalori 1 kg sekam sebesar $3300 \mathrm{k}$. kalori, serta memiliki bulk density $0,100 \mathrm{~g} / \mathrm{ml}$, nilai kalori antara 3300 -3600 kkalori/kg sekam dengan konduktivitas panas 0,271 BTU (Houston, 1972). Sekam dikategorikan sebagai biomassa yang dapat digunakan untuk berbagai kebutuhan seperti bahan baku industri, pakan ternak dan energi atau bahan bakar ataupun sebagai adsorpsi pada logam-logam berat. Sekam tersusun dari jaringan serat-serat selulosa yang mengandung banyak silika dalam bentuk serabut-serabut yang sangat keras. Pada keadaan normal, sekam berperan penting melindungi biji beras dari kerusakan yang disebabkan oleh serangan jamur, dapat mencegah reaksi ketengikan karena dapat melindungi lapisan tipis yang kaya minyak terhadap kerusakan mekanis selama pemanenan, penggilingan dan pengangkutan. ( Haryadi. 2006 ).

Adapun kegiatan yang dilakukan meliputi (1) Survey awal untuk mengetahui tingkat pengetahuan mitra, kondisi lingkungan dan proses perijinan, (2) Koordinasi dengan perangkat desa dan mitra untuk menentukan waktu, tempat pelaksanaan serta materi yang dibutuhkan mitra. (3) Penyiapan peralatan dan perlengkapan pelatihan. (4) Penyusunan modul/materi pelatihan. (5) Praktek pembuatan batu bata. (6) Praktek pemupukan. (7) Praktek pengambilan tanah.

Partisipasi mitra dalam pelaksanakan program IbM ini meliputi 1) Penyediaan tanah 2) Penyediaan lokasi 3) Penyediaan peralatan dan prasarana pembuatan batu bata

\section{HASIL KEGIATAN}

Kegiatan telah dilaksanakan sesuai rencana yakni dengan melakukan pembimbingan terhadap mitra, baik mitra 1 (UKM Pengusaha Batu Bata "Suko Makmur") maupun mitra 2 (Kelompok Tani "Krido Tani"). Terhadap mitra 1 dilakukan pembimbingan dalam hal pengelolaan sumber bahan pembuatan batu bata yaitu tanah lempung yang bisa diambil dari sawah di daerah sekitar, dengan sifat-sifat tanah tertentu yang cocok sebagai bahan batu bata, sedangkan terhadap mitra 2 dilakukan pembimbingan dalam hal pengolahan lahan sawah secara lebih efektif dan ekonomis.

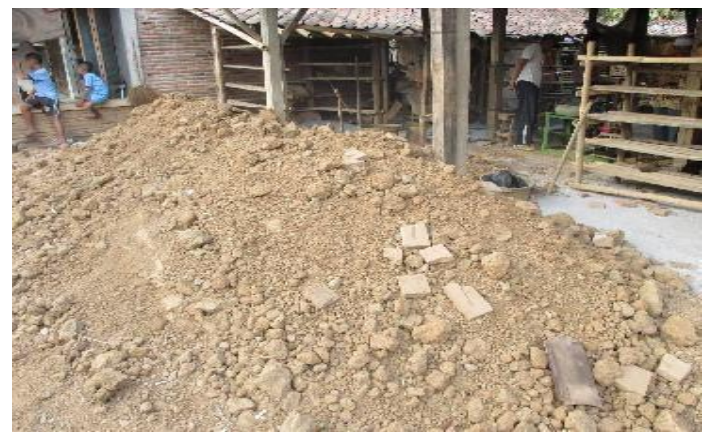

Gambar 1. Bahan Pembuat Batubata

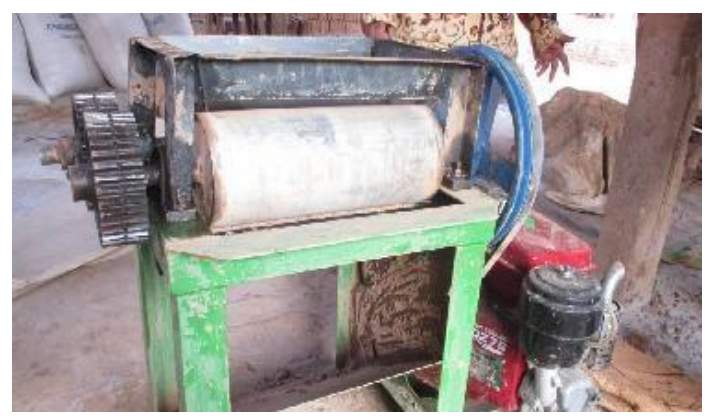

Gambar 2. Mesin Penghalus tanah sebagai bahan batubata

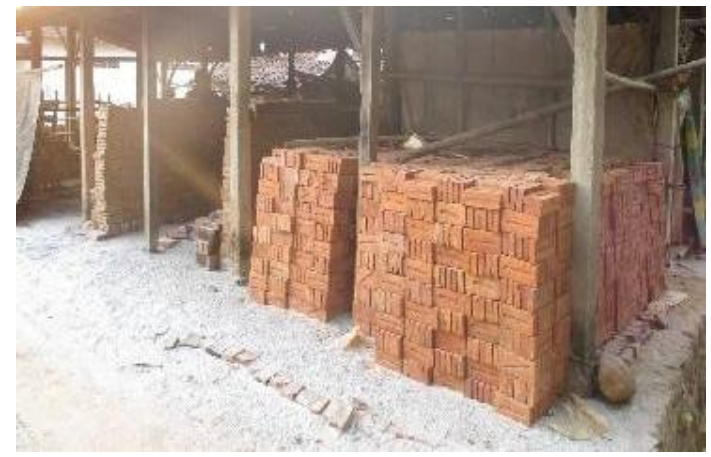

Gambar 3. Produk Batubata yang dihasilkan 


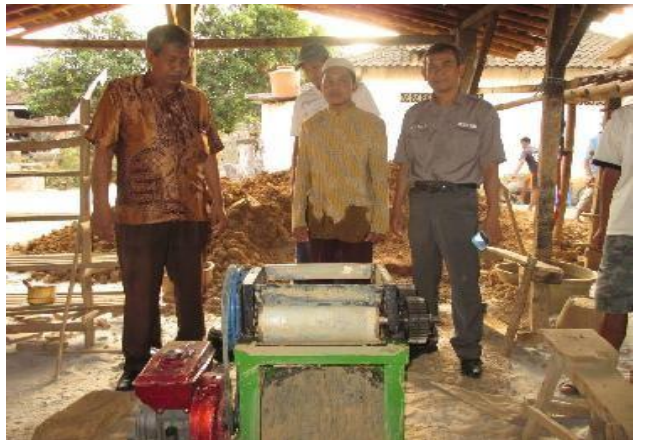

Gambar 4. Tim Pengabdi bersama Mitra

Kedua mitra merasakan manfaat dari kegiatan pengabdian ini cukup besar karena bagi mitra 1 sumber bahan pembuatan batu bata yang utama adalah tanah lempung yang memiliki sifat-sifat tertentu, mudah didapat dan murah. Di daerah sekitar lokasi usaha batu bata terdapat sumber bahan tersebut berupa tanah sawah yang dimiliki petani yang keadaannya tidak rata antar petak yang kecil-kecil.

Dari kondisi tersebut timbullah ide untuk mengambil tanah dari petak sawah yang tinggi sehingga menjadi rata dengan petak yang lebih rendah. Dengan demikian maka terbentuk luasan sawah yang lebih besar. Manfaat bagi mitra 2 adalah terbentuknya lahan sawahnya yang lebih luas sehingga dapat diolah menggunakan traktor tangan. Sebelumnya tidak dapat diolah menggunakan traktor tangan karena luasan yang sempit tidak memungkinkan traktor tangan bergerak memutar balik sehingga pengolahan tanah dilakukan dengan mencangkulnya yang memakan waktu lama dan biaya yang lebih besar.

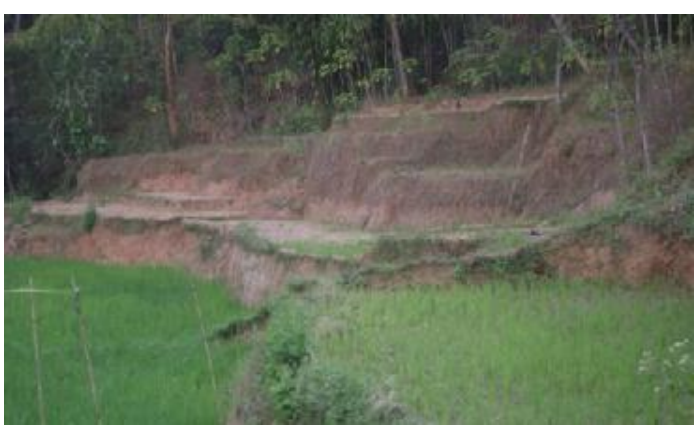

Gambar 5. Kondisi lahan Mitra 2.

\section{KESIMPULAN DAN SARAN}

\section{Kesimpulan}

Pelaksanaan kegiatan ini dilakukan dengan cara bersama-sama dengan mitra untuk mengidentifikasi permasalahan, kebutuhan serta melakukan perencanaan sampai pelaksanaan kegiatan :

Kegiatan dilakukan dengan menghubungkan/ mempertemukan dengan petani yang mempunyai tanahtanah yang lahannya berteras kecil/sempit sehingga memperbaiki bentuk lahan dengan cara memperlebar teras tanah dari 2 sampai 3 bidang teras menjadi 1 bidang teras. Hal ini akan memulihkan tingkat kesuburan/kualitas tanah bekas galian pengambilan bahan baku batu bata, salah satunya dengan memanfaatkan abu limbah pembakaran batu bata.

\section{Saran}

Kegiatan memperbaiki bentuk lahan dengan cara memperlebar teras tanah dari 2 sampai 3 bidang teras menjadi 1 bidang teras dapat dilanjutkan secara mandiri oleh mitra. Adanya penyebaran informasi tentang pemanfaatkan abu limbah pembakaran batu bata untuk memulihkan tingkat kesuburan/kualitas tanah bekas galian pengambilan bahan baku batu bata. 


\section{DAFTAR PUSTAKA}

Mardiyati, I. dan Harjana. 2010. Optimasi Suhu Pembakaran Batubata Merah Dengan Penambahan Limbah Batubara Untuk Meningkatkan Kualitas Batubata Merah. Prosiding Pertemuan Ilmiah XXIV HFI Jateng \& DIY, Semarang 10 April 2010317 hal. 317322. ISSN: 0853 - 0823.

Notohadiprawiro, T. 2000. Tanah dan Lingkungan. Pusat Studi Sumberdaya Lahan, UGM. Yogyakarta.

Handayani, S. 2010. Kualitas Batu Bata merah dengan penambahan serbuk gergaji. Jurnal Teknik Sipil dan Perencanaan. Nomor 1 Vol. 12. Januari 2010. Hal. 41 - 50.

Husen, E., A. Rachman, Irawan dan F. Agus. 2005. Multifungsi Pertanian dan Ketahanan Pangan. Prosiding Seminar Nasional. 12 Oktober dan 24
Desember 2004. Pusat Penelitian Dan Pengembangan Tanah Dan Agroklimat. Badan Penelitian Dan Pengembangan Pertanian. Departemen Pertanian.

Partohardjono, S. dan M. Syam. 1992. Pengembangan Terpadu Pertanian Lahan Rawa Pasang Surut dan Lebak. Risalah Pertemuan Nasional Pengembangan Pertanian Lahan Rawa Pasang Surut dan Lebak. Cisarua, 3 - 4 Maret 1992. Badan Penelitian Dan Pengembangan Tanaman Pangan. Badan Penelitian Dan Pengembangan Pertanian. Deptan.

Wulari, F. I. 2011. Pengaruh Penambahan Serbuk Gergaji Kayu Jati (Tectona Grandits L.F), Pada Paduan Tanah Liat Dan Abu Sampah Terhadap Kualitas Batu Bata Merah Di Kabupaten Karanganyar. FMIPA UNS. Skripsi. 